\title{
THE EFFECT OF MARKETING STRATEGY AND PROMOTION ACTIVITIES ON MARKETING PERFORMANCE OF RETAIL BUSINESS
}

\author{
Suhandi \\ Universitas Pamulang, Indonesia \\ dosen02501@unpam.ac.id
}

\begin{abstract}
Today's retail industry is experiencing rapid development along with technological advances and the construction of supporting facilities. Tangerang is one of the cities that is part of the Banten Province which is growing rapidly. rapid modernization affected the city, making it one of the largest cities in Indonesia. This study aims to determine the effect of marketing strategies and promotional activities on the marketing performance of Retail Business Actors in Mall Plaza Bintaro. The method used was explanatory research with a sample of 96 respondents. The analysis technique uses statistical analysis with regression testing, correlation, determination, and hypothesis testing. The results of this study the marketing strategy has a significant effect on marketing performance by $38.2 \%$, the hypothesis test obtained $t$ count $>\mathrm{t}$ table or (7.625> 1.989). Promotional activities have a significant effect on marketing performance by $39.9 \%$, the hypothesis test obtained $t$ count $>t$ table or (7.892> 1.989). Marketing strategy and promotion activities simultaneously have a significant effect on marketing performance by $48.9 \%$, the hypothesis test is obtained $\mathrm{F}$ count> F table or (44.464>2,700).
\end{abstract}

Keywords: Marketing Strategy, Promotion Activities, Marketing Performance

\section{INTRODUCTION}

Today's retail industry is experiencing rapid development along with technological advances and the construction of supporting facilities. Tangerang is one of the cities that is part of the Banten Province which is growing rapidly. rapid modernization affected the city, making it one of the largest cities in Indonesia. With the city busy, lifestyle, and lack of tourist attractions, many residents who choose an alternative tour to the big mall in the city with the current mall not only serves to serve the shopping needs of the community but is used as a relaxing break on weekends. Traditionally the word mall has a mean usually lined with shade trees and is used as a public walk or promenade. The mall is a shopping center with a core of one or several large department stores as an attraction of small retail shops and restaurants with building typology such as a shop overlooking the main corridor of the mall or conservation which is the main element of a shopping mall (mall), with the function as circulation and as a communal space for the interaction between visitors and traders.

As a tertiary industry or an industry engaged in services, fulfilling needs and entertainment, tenants and visitors are the driving force of this company's economic wheel. The number of tenants in a mall will affect the number of mall visitors. Consumers prefer shopping centers that provide a different experience compared to others. Most of the physical design where the design also adds to the tenant fillers there. The shopping center as a product that is designed must function following the expectations of the designer that can be adapted to the conditions of the existing community, both economic benefits and emotional benefits that are formed by consumers. This is also consistent with the opinion According to Paul (1982) cited Mani (2018) that Effective strategies can see in the most developed places through means to achieve goals in marketing.

The development of retail businesses needs to be implemented to utilize the land facilities provided by Mall Plaza Bintaro. As a means of fulfilling a consumptive lifestyle, many 
shops are available for rent. Emphasis on rental prices is applied to attract tenants to want to rent in this mall. Mall management also provides seminars related to providing business to run the businesses of tenants and providing shopping facilities and other public facilities as visitors dance power.

Table 1. Plaza Bintaro Mall Visitor Traffic

\begin{tabular}{cccc}
\hline Year & Car & $\begin{array}{c}\text { Visitor year } \\
\text { Motor }\end{array}$ & Visitor \\
\hline 2013 & 775.914 & 1.214 .093 & 14.556 .109 \\
2014 & 667.384 & 851.929 & 14.904 .003 \\
2015 & 673.951 & 824.887 & 11.679 .073 \\
2016 & 591.931 & 824.887 & 9.256 .365 \\
2017 & 533.496 & 772.317 & 9.472 .382 \\
2018 & 414.747 & 623.259 & 7.275 .869 \\
\hline
\end{tabular}

Source: processed data (2020)

From the data table above, it can be seen that the Plaza Bintaro Mall visitors are decreasing from year to year. Lack of innovation, superior competitors, and the number of tenants who close their shops are the main factors for the quiet of this mall. Traffic data from September 2018 recorded that there were 452 active tenants, but in August 2019 there were only 397 units left registered. So, approximately within a period of one year, 55 units of tenants closed their shops in Mall Plaza Bintaro.

Using marketing strategies in retail business and product marketing performance is a fairly efficient and effective way to improve marketing performance. According to Kotler (2015) marketing is the marketing mindset that will be used to achieve its marketing goals. Marketing strategies contain specific strategies for targeting, positioning, market mix, and the number of marketing expenses. The marketing mix is a tactical marketing tool and can be controlled by-products, prices, distribution and promotion which are integrated by the company to produce responses that the company wants in the target market (Kotler, 2015).

Promotion as one of the variables of the marketing mix has been implemented to the number of visitors. According to Kotler (2015) promotion of marketing performance is a short-term incentive to encourage desire and to try or buy a product and service. For example, a product (sample) is a specific product offer for an experiment. A similar sentiment was also conveyed that by seeing the importance of promotion, it is appropriate for the company to consider an advertising concept that is truly on target so that it can support the company's success (Jasmani, 2018). Therefore, Plaza Bintaro Mall Management always held an event that involved all tenants to work together to increase visitors at Plaza Bintaro Mall.

As for the promotion carried out to increase the volume of visitors as follows the manager carries out promotional activities such as Beauty Inspiring Hijab, Advanced Snacks, Happy Coloring Competition, and Sunday Jumping Performance. Painting competition, cheerful kids gymnastics. This activity was held to promote the Plaza Mall Bintaro is still less effective. Characterized by not increasing the number of visits to the mall, due to lack of public interest. This could threaten the sustainability of the mall business.

The number of variables that are explained that play an important role in marketing activities to increase the increase in marketing performance of Mall Plaza Bintaro. The researcher is interested in conducting a research 
activity entitled "Effect of Marketing Strategy and Promotion Activities on the marketing performance of Retail Business Actors in Mall Plaza Bintaro.

Formulation of the problem: (1) Is there a partial influence between marketing strategy on marketing performance of Retail Business Actors in Mall Plaza Bintaro; (2) Is there a partial effect between promotional activities on marketing performance of Retail Business Actors at Mall Plaza Bintaro. (3) Is there a simultaneous influence between marketing strategies and promotional activities on marketing performance of Retail Business Actors at Mall Plaza Bintaro.

Research purposes: (1) To find out a partial effect between marketing strategies on the marketing performance of Retail Business Actors in Mall Plaza Bintaro; (2) To find out the partial effect between promotional activities on the marketing performance of Retail Business Actors in Mall Plaza Bintaro; (3) To find out the simultaneous influence between marketing strategies and promotional activities on the marketing performance of Retail Business Actors in Mall Plaza Bintaro.

According to Stanton (2016) Marketing strategy is a matter that covers all systems related to the aim to plan and set the price of a product to market it and distribute goods and services that can give satisfaction to actual and potential buyers. In a marketing strategy, there are basic actions that lead to the company's marketing activities. Competitive conditions and environments that can always change with the hope of achieving the desired goal. Before marketing strategies are used in a company, market conditions must be seen as well as assessing the position in the market, it aims to determine what marketing activities are appropriate to be applied in the market. When all things have been done well, the marketing strategy said to be successful or successful is seen from the achievement of a level of satisfaction expected by a company. That is, the goal of marketing the desired product leads to customer satisfaction

According to Kotler \& Keller (2016) argues Promotion is a special ingredient of personal advertising, sales promotion and public relations that companies use to achieve advertising and marketing goals. According to Babin (2017) while Promotion is a communication function of the company responsible for informing and persuading/inviting buyers. In another case with Tjiptono \& Gregourius (2017) Sales promotion is a form of direct persuasion through the use of various incentives that can be arranged to stimulate product purchases immediately and increase the number of goods purchased by customers.

Saunila \& Ukko (2016) define measurement as the process of measuring the efficiency and effectiveness of actions. Performance measurement can also be defined as measuring the input, output, or activity level of an event or process. Furthermore, Saunila \& Ukko (2016) explain that the performance measurement framework has its uses but only provides guidance for how steps should be identified, introduced, and used for management purposes. The strength of a performance measurement framework lies in how it pays attention to the different steps of business performance - financial and non-financial, internal and external.

\section{METHODS}

The population in this study amounted to 96 respondents Plaza Bintaro Mall. The sampling technique in this study is saturated sampling, where all members of the population are sampled. Thus the sample in this study amounted to 96 respondents. The type of research used is associative, where the aim is to find out the relationship between variables. In analyzing the data used the instrument test, classical 
assumption test, regression, coefficient of determination, and hypothesis testing.

\section{RESULTS AND DISCUSSION Descriptive Analysis}

This test used to determine the minimum and maximum scores, mean scores, and standard deviations of each variable. The results are as follows:

Table 1. Results of Descriptive Statistics Analysis

\begin{tabular}{lcrrrr}
\hline & \multicolumn{3}{c}{ Descriptive Statistics } & & \\
& N & Minimum & Maximum & Mean & $\begin{array}{c}\text { Std. } \\
\text { Deviation }\end{array}$ \\
Marketing Strategy (X1) & 96 & 32 & 48 & 38.29 & 3.693 \\
Promotional Activities (X2) & 96 & 30 & 45 & 38.31 & 3.697 \\
Marketing Performance & 96 & 32 & 46 & 39.20 & 3.423 \\
(Y) & 96 & & & \\
Valid N (listwise) & & & & \\
\hline \multicolumn{5}{l}{ Source: processed data (2020) }
\end{tabular}

The marketing strategy obtained a minimum variance of 32 and a maximum variance of 48 with a mean score of 3.83 with a standard deviation of 3.693.

Promotional activities obtained a minimum variance of 30 and a maximum variance of 45 with a mean score of 3.83 with a standard deviation of 3.697 .

Marketing performance obtained a minimum variance of 32 and a maximum variance of 46 with a mean score of 3.92 with a standard deviation of 3.423 .

\section{Verification Analysis}

This analysis is intended to determine the effect of independent variables on the dependent variable. The test results are as follows:

\section{Multiple Linear Regression Analysis}

This regression test is intended to determine changes in the dependent variable if the independent variable changes. The test results are as follows:

Table 2. Results of Multiple Linear Regression Testing

\begin{tabular}{|c|c|c|c|c|c|c|}
\hline \multirow{3}{*}{\multicolumn{2}{|c|}{ Model }} & \multicolumn{3}{|c|}{ Coefficients $^{a}$} & \multirow{3}{*}{$\mathrm{t}$} & \multirow{3}{*}{ Sig. } \\
\hline & & \multicolumn{2}{|c|}{$\begin{array}{l}\text { Unstandardized } \\
\text { Coefficients }\end{array}$} & \multirow{2}{*}{$\begin{array}{c}\text { Standardized } \\
\text { Coefficients } \\
\text { Beta }\end{array}$} & & \\
\hline & & B & $\begin{array}{l}\text { Std. } \\
\text { Error }\end{array}$ & & & \\
\hline & (Constant) & $\begin{array}{r}11.44 \\
8\end{array}$ & 2.954 & & 3.875 & .000 \\
\hline & $\begin{array}{l}\text { Marketing Strategy } \\
\text { (X1) }\end{array}$ & .347 & .086 & .375 & 4.052 & .000 \\
\hline & $\begin{array}{l}\text { Promotional } \\
\text { Activities (X2) }\end{array}$ & 377 & .086 & .407 & 4.406 & .000 \\
\hline
\end{tabular}

Activities (X2)

a. Dependent Variable: Marketing Performance $(\mathrm{Y})$

Source: processed data (2020)

Based on the test results in the above table, the regression equation $Y$ $=11.448+0.347 \mathrm{X} 1+0.377 \mathrm{X} 2$ is obtained. From the equation explained as follows: 
A constant of 11,448 means that if there are no marketing strategies and promotional activities, then there is a marketing performance value of 11,448 points. The marketing strategy regression coefficient of 0.347 , this number is positive, meaning that every time there is a marketing strategy of 0.347 , marketing performance will also experience 0.347 points. The regression coefficient of promotional activities is 0.377 , this number is positive, meaning that every time there is a promotional activity of 0.377 , marketing performance will also experience 0.377 points.

\section{Correlation Coefficient Analysis}

Correlation coefficient analysis is intended to determine the degree of relationship strength of the independent variables on the dependent variable either partially or simultaneously. The test results are as follows:

Table 3. Correlation Coefficient Test Results Marketing strategies on marketing

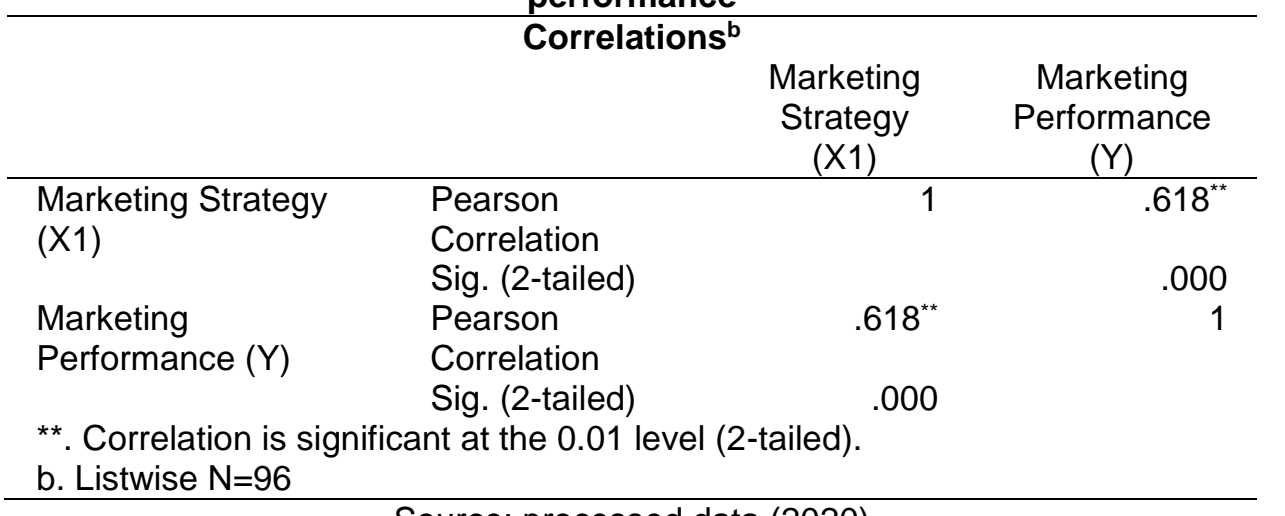

Source: processed data (2020)

Based on the test results strong relationship to marketing obtained a correlation value of 0.618 means that marketing strategies have a performance.

Table 4. Correlation Coefficient Testing Results Promotion activities on marketing performance

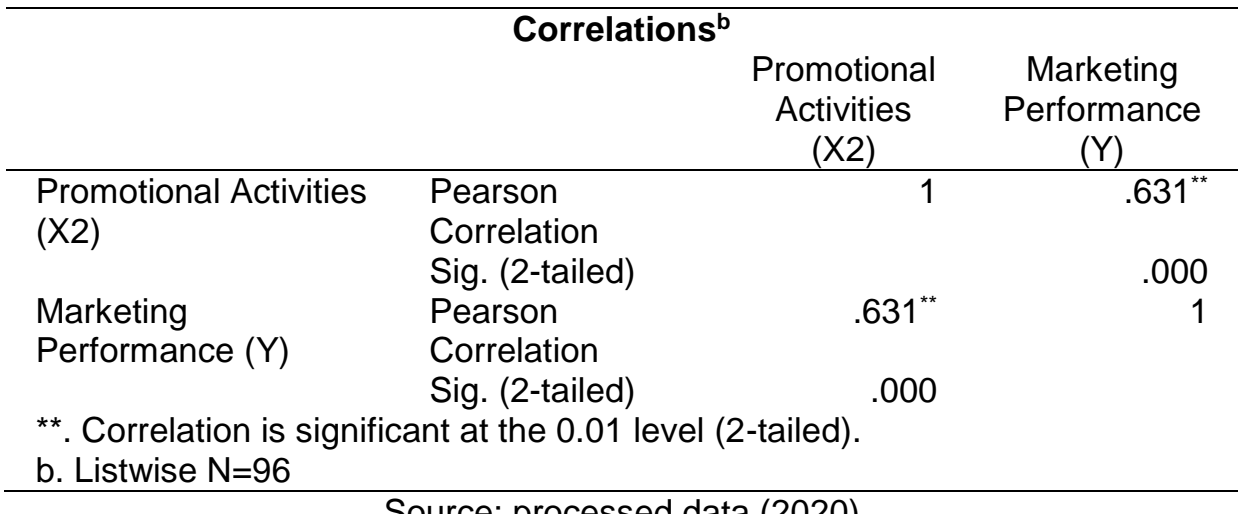

Source: processed data (2020)

Based on the test results obtained a correlation value of 0.631 means that promotional activities have a strong relationship to marketing performance. 
Table 5. Correlation Coefficient Test Results Marketing strategies and promotional activities simultaneously on marketing performance

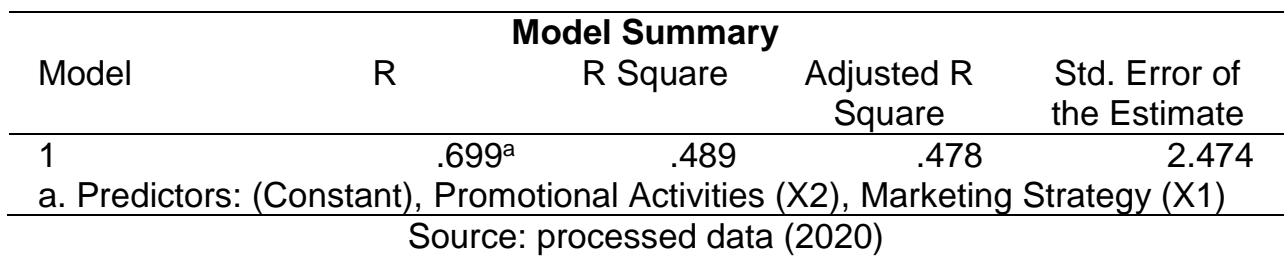

Based on the test results obtained a correlation value of 0.699 means that marketing strategies and promotional activities simultaneously have a strong relationship to marketing performance.

\begin{abstract}
Analysis of the Coefficient of Determination

Analysis of the coefficient of determination is intended to determine the percentage of influence of the independent variable on the dependent variable either partially or simultaneously. The test results are as follows:
\end{abstract}

Table 6. Test Results for the Coefficient Determination of Marketing Strategies on marketing performance

\begin{tabular}{lcccr}
\hline Model & \multicolumn{3}{c}{ Model Summary } \\
R Square & $\begin{array}{c}\text { Adjusted R } \\
\text { Square }\end{array}$ & $\begin{array}{c}\text { Std. Error of } \\
\text { the Estimate }\end{array}$ \\
\hline 1 & & .382 & .376 & 2.705 \\
a. Predictors: (Constant), Marketing Strategy $(\mathrm{X} 1)$ & \\
\hline \multicolumn{4}{c}{ Source: processed data (2020) }
\end{tabular}

Based on the test results obtained a determination value of 0.382 means that marketing strategies have an influence contribution of $38.2 \%$ on marketing performance.

Table 7. Test Results for the Coefficient of Determination Promotion activities on marketing performance

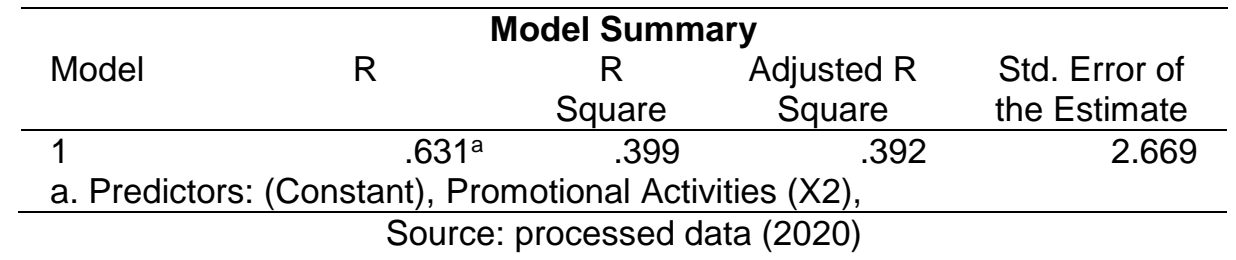

Based on the test results obtained a determination value of 0.399 means that promotional activities have an influence contribution of $39.9 \%$ on marketing performance. 
Table 8. Test Results for the Coefficient Determination of Marketing Strategies and Promotion Activities on marketing performance

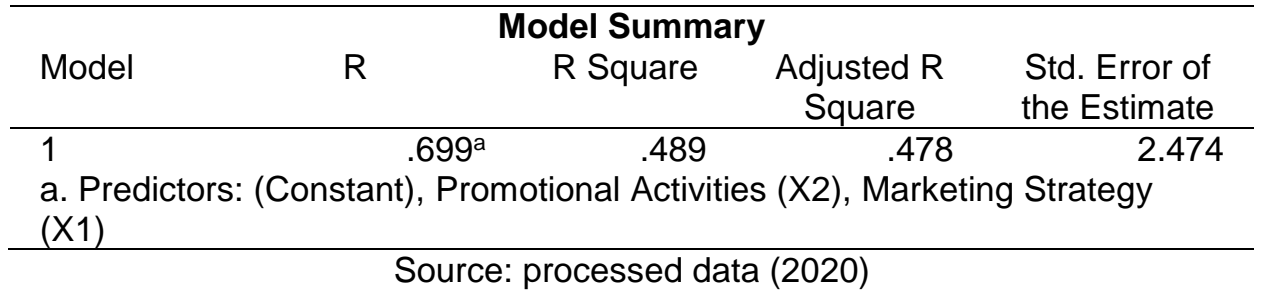

Based on the test results obtained a determination value of 0.489 means that the marketing strategy and promotional activities simultaneously have an influence contribution of $48.9 \%$ on marketing performance, while the remaining $51.1 \%$ is influenced by other factors.

\begin{abstract}
Hypothesis testing
Hypothesis testing with a t-test is used to find out which partial hypotheses are accepted.

First Hypothesis: There is a significant influence between marketing strategies on marketing performance.
\end{abstract}

Table 9. Hypothesis Test Results Marketing strategies on marketing performance

\begin{tabular}{|c|c|c|c|c|c|}
\hline \multirow{3}{*}{ Model } & \multicolumn{3}{|c|}{ Coefficients $^{\mathrm{a}}$} & \multirow{3}{*}{$\mathrm{t}$} & \multirow{3}{*}{ Sig. } \\
\hline & \multicolumn{2}{|c|}{$\begin{array}{l}\text { Unstandardized } \\
\text { Coefficients }\end{array}$} & \multirow{2}{*}{$\begin{array}{c}\text { Standardized } \\
\text { Coefficients } \\
\text { Beta }\end{array}$} & & \\
\hline & B & $\begin{array}{l}\text { Std. } \\
\text { Error }\end{array}$ & & & \\
\hline $\begin{array}{ll}1 & \text { (Constant) }\end{array}$ & $\begin{array}{r}17.25 \\
8\end{array}$ & 2.891 & & 5.970 & .000 \\
\hline $\begin{array}{l}\text { Marketing Strategy } \\
(\mathrm{X} 1) \\
\text { a. Dependent Variable }\end{array}$ & .573 & .075 & .618 & 7.625 & .000 \\
\hline
\end{tabular}

Based on the test results in the above table, the value of $t$ count $>t$ table or (7.625> 1.989) is obtained, thus the first hypothesis proposed that there is a significant influence on the marketing strategy on marketing performance is accepted.

Table 10. Hypothesis Test Results from Promotional activities on marketing performance.

\begin{tabular}{|c|c|c|c|c|c|}
\hline \multirow{3}{*}{ Model } & \multicolumn{3}{|c|}{ Coefficients $^{a}$} & \multirow{3}{*}{$\mathrm{t}$} & \multirow{3}{*}{ Sig. } \\
\hline & \multicolumn{2}{|c|}{$\begin{array}{l}\text { Unstandardized } \\
\text { Coefficients }\end{array}$} & \multirow{2}{*}{$\begin{array}{l}\text { Standardized } \\
\text { Coefficients } \\
\text { Beta }\end{array}$} & & \\
\hline & B & $\begin{array}{l}\text { Std. } \\
\text { Error }\end{array}$ & & & \\
\hline 1 (Constant) & $\begin{array}{r}16.80 \\
4\end{array}$ & 2.850 & & 5.895 & .000 \\
\hline $\begin{array}{c}\text { Promotional } \\
\text { Activities (X2), } \\
\text { a. Dependent Vari }\end{array}$ & .585 & erforma & $(Y)$ & 7.892 & .000 \\
\hline
\end{tabular}

Source: processed data (2020)

Based on the test results in the table above, the value of $t$ count $>t$ table or (7.892> 1.989) is obtained, thus the second hypothesis proposed that there is a significant influence 
between promotional activities on marketing performance is accepted.

Hypothesis testing with the F test is used to find out which simultaneous hypotheses are accepted.
The third hypothesis There is a significant influence between marketing strategies and promotional activities on marketing performance.

\section{Table 11. Hypothesis Test Results Marketing strategies and promotional activities on marketing performance}

\begin{tabular}{|c|c|c|c|c|c|c|}
\hline \multirow{2}{*}{\multicolumn{2}{|c|}{ Model }} & \multicolumn{3}{|c|}{ ANOVA $^{\mathrm{a}}$} & \multirow[b]{2}{*}{$\mathrm{F}$} & \multirow[b]{2}{*}{ Sig. } \\
\hline & & $\begin{array}{l}\text { Sum of } \\
\text { Squares }\end{array}$ & df & $\begin{array}{l}\text { Mean } \\
\text { Square }\end{array}$ & & \\
\hline \multirow[t]{3}{*}{1} & Regression & 544.162 & 2 & 272.081 & 44.464 & $.000^{\mathrm{b}}$ \\
\hline & Residual & 569.077 & 93 & 6.119 & & \\
\hline & Total & 1113.240 & 95 & & & \\
\hline \multicolumn{7}{|c|}{$\begin{array}{l}\text { a. Dependent Variable: Marketing Performance (Y) } \\
\text { b. Predictors: (Constant), Promotional Activities (X2), Marketing Strategy (X1) }\end{array}$} \\
\hline
\end{tabular}

Based on the test results in the above table, the calculated $\mathrm{F}$ values $\mathrm{F}$ table or (44.464>2,700), thus the third hypothesis proposed that there is a significant influence between marketing strategy and promotional activities on marketing performance is accepted.

\section{Effect of marketing strategies on marketing performance}

The marketing strategy has a significant effect on marketing performance with a correlation of 0.618 or has a strong relationship with a contribution of $38.2 \%$. Hypothesis testing obtained $\mathrm{t}$ value $>\mathrm{t}$ table or (7.625> 1.989). Thus the first hypothesis proposed that there is a significant effect between marketing strategies on marketing performance is accepted.

\section{Effect of promotional activities on marketing performance \\ Promotional activities have a} significant effect on marketing performance with a correlation of 0.631 or have a strong relationship with an influential contribution of $39.9 \%$. Hypothesis testing obtained $\mathrm{t}$ value $>\mathrm{t}$ table or (7.892> 1.989). Thus the second hypothesis proposed that there is a significant effect between promotional activities on marketing performance is accepted.

\section{Effect of marketing strategies and promotional activities on marketing performance}

Marketing strategy and promotion activities have a significant effect on marketing performance by obtaining a regression equation $\mathrm{Y}=11,448+$ $0,347 X 1+0,377 X 2$, a correlation value of 0,699 , or having a strong relationship with a contributing effect of $48.9 \%$ while the remaining $51.1 \%$ is influenced by factors other. Hypothesis testing obtained $F$ value> $F$ table or (44.464> $2,700)$. Thus the third hypothesis proposed that there is a significant effect between marketing strategies and promotional activities on marketing performance is accepted.

\section{CONCLUSION}

The marketing strategy has a significant effect on marketing performance. Hypothesis testing is obtained $t_{\text {count }}>t_{\text {table. }}$. Promotion activities have a significant effect on marketing performance Hypothesis testing is obtained $t_{\text {count }}>t_{\text {table. }}$ Marketing strategies and promotional activities have a significant effect on marketing performance. Hypothesis testing is obtained by calculating the value of $F>$ $\mathrm{F}$ table. 
REFERENCES

Babin, Almohaimmeed. (2017).

Restaurant Quality and Customer

Satisfaction. International Review of Management and Marketing. 7(3).

Jasmani, J. (2018). Pengaruh Promosi Dan Pengembangan Produk Terhadap Peningkatan Hasil Penjualan. Jurnal Semarak, 1(3).

Kotler (2015). Manajemen Pemasaran. Edisi Keempat belas, Jakarta: PT. Indeks.

Kotler, Philip \& Keller, Kevin Lane (2016). Marketing Management 15th Edition. New Jersey: Prentice-Hall.

Mani, J. (2018). Pengaruh Peran Nilai Pelanggan Dan Citra Merek Terhadap Kinerja Pemasaran. Jurnal Mandiri, 2(2), 263-280.

Saunila, M \& Ukko. (2016). Performance measurement approach for innovation capability in SMEs. International Journal of Productivity and Performance Management, 65(2), 162-17

Tjiptono. F \& Gregourius, C (2017). Pemasaran Strategik. Yogyakarta: Andi (Anggota IKAPI)

Stanton, Wiliam J. (2016.) PrinsipPrinsip Pemasaran, Edisi ketujuh, Jakarta: Erlangga. 